\title{
Review \\ Molecular Minimal Residual Disease Detection in Acute Myeloid Leukemia
}

\author{
Christian M. Vonk ${ }^{1}$, Adil S. A. Al Hinai ${ }^{1,2}$, Diana Hanekamp ${ }^{1,3}$ and Peter J. M. Valk ${ }^{1, *}$ \\ 1 Department of Hematology, Erasmus MC Cancer Institute, University Medical Center Rotterdam, \\ 3015 CN Rotterdam, The Netherlands; c.m.vonk@erasmusmc.nl (C.M.V.); \\ adilsalim.alhinai@moh.gov.om (A.S.A.A.H.); d.hanekamp@erasmusmc.nl (D.H.) \\ 2 National Genetic Center, Ministry of Health, Muscat 111, Oman \\ 3 Department of Hematology, Cancer Center VU University Medical Center, Amsterdam University Medical \\ Centers, 1081 HV Amsterdam, The Netherlands \\ * Correspondence: p.valk@erasmusmc.nl; Tel.: +31-10-7043975
}

Citation: Vonk, C.M.; Al Hinai, A.S.A.; Hanekamp, D.; Valk, P.J.M. Molecular Minimal Residual Disease Detection in Acute Myeloid Leukemia. Cancers 2021, 13, 5431. https://doi.org/10.3390/cancers13215431

Academic Editors: Frederik Damm and Lars B. Bullinger

Received: 5 October 2021

Accepted: 25 October 2021

Published: 29 October 2021

Publisher's Note: MDPI stays neutral with regard to jurisdictional claims in published maps and institutional affiliations.

Copyright: (c) 2021 by the authors. Licensee MDPI, Basel, Switzerland. This article is an open access article distributed under the terms and conditions of the Creative Commons Attribution (CC BY) license (https:// creativecommons.org/licenses/by/ $4.0 /)$.
Simple Summary: Although the majority of patients with acute myeloid leukemia (AML) reach a morphologic complete remission after high-dose chemotherapy, the majority of them face a relapse within a few years. Detection of residual cells, persisting in a considerably small amount, has shown to be predictive of impending relapse in multiple studies. Whereas the gold standard in minimal residual disease (MRD) detection in AML is currently based on immunophenotypic approaches, the use of molecular MRD testing to predict AML relapse has been explored extensively in recent years. This review aims to provide an overview of the different studies that improve molecular MRD detection in AML, and to describe the limitations and challenges it faces.

Abstract: Initial induction chemotherapy to eradicate the bulk of acute myeloid leukemia (AML) cells results in complete remission (CR) in the majority of patients. However, leukemic cells persisting in the bone marrow below the morphologic threshold remain unaffected and have the potential to proliferate and re-emerge as AML relapse. Detection of minimal/measurable residual disease (MRD) is a promising prognostic marker for AML relapse as it can assess an individual patients risk profile and evaluate their response to treatment. With the emergence of molecular techniques, such as next generation sequencing (NGS), a more sensitive assessment of molecular MRD markers is available. In recent years, the detection of MRD by molecular assays and its association with AML relapse and survival has been explored and verified in multiple studies. Although most studies show that the presence of MRD leads to a worse clinical outcome, molecular-based methods face several challenges including limited sensitivity/specificity, and a difficult distinction between mutations that are representative of AML rather than clonal hematopoiesis. This review describes the studies that have been performed using molecular-based assays for MRD detection in the context of other MRD detection approaches in AML, and discusses limitations, challenges and opportunities.

Keywords: acute myeloid leukemia; minimal/measurable residual disease; MRD; next generation sequencing; clonal hematopoiesis

\section{Introduction}

Acute Myeloid Leukemia (AML) is a stem cell disorder within the hematopoietic system arising from aberrant proliferation of undifferentiated myeloid progenitor cells and is characterized by a considerable clonal and genetic heterogeneity [1]. In recent years, advancements have been made in understanding the genetic and molecular landscape underlying AML [2]. With the emergence of novel and more sensitive techniques, such as whole-genome sequencing and whole-exome sequencing (WGS, and WES, respectively), detailed analyses of the disease have become feasible and more efficient. 
At the time of AML diagnosis, a classification and risk assessment is made depending on morphologic, immunophenotypic, cytogenetic and molecular aberrations present in the patients' bone marrow (BM). The (cyto)genetic markers allow for a classification into different molecular subgroups with distinct prognostic outcomes; favorable, intermediate, or adverse as summarized in the 2017 European LeukemiaNet (ELN) recommendations for diagnosis and management of AML [3]. This classification forms the basis upon which treatment decisions are made, where patients in the adverse-risk group are considered for allogeneic stem cell transplantation and the favorable risk-group patients are not. Treatment is generally started with intensive induction chemotherapy to eradicate the bulk of leukemic cells, after which a majority of the AML patients reach a morphologic complete remission (CR) [4]. However, relapse rates are still high, affecting more than $50 \%$ of patients within a few years after diagnosis [5].

Currently, post-treatment analysis is generally conducted morphologically, where CR is defined as $<5 \%$ blast cells remaining in the bone marrow [4]. However, leukemic cells that reside below this morphologic threshold are unaffected by chemotherapy and have the potential to re-emerge as disease relapse. The ability to detect these small persisting cell populations early on has the potential to guide physicians in deciding to change treatment and prevent patients from relapse [6,7]. Molecular minimal/measurable residual disease (MRD) detection permits a highly sensitive evaluation of an individual patient's relapse risk and response to treatment, making it a promising prognostic marker in AML.

\section{Minimal/Measurable Residual Disease}

MRD is defined as the persistence of a small number of malignant cells after initial treatment, undetectable by conventional screening methods, yet measurable by more sophisticated technologies. The residual cells are often present without clinical signs or symptoms of the disease, but can potentially be used as a predictive or prognostic biomarker when detected [7]. Several assays are currently available for the detection of MRD, which can be grouped into two different approaches: immunophenotypic, with multiparameter flow cytometry (MFC), and molecular, with real-time quantitative polymerase chain reaction (RQ-PCR), digital droplet PCR (ddPCR) and/or next generation sequencing (NGS). Each of these methods differs in their applicability, specificity and sensitivity of detecting MRD.

\subsection{Multiparameter Flow Cytometry Approaches}

The introduction of MFC in routine diagnostics allowed a more detailed and sensitive examination of BM for both diagnosis and MRD detection of AML [8,9]. MFC-based MRD detection relies on the presence of immunophenotypic aberrant antigen expression where leukemic cells can be discriminated from normal cells by leukemia-associated immunophenotypes (LAIPs). LAIPs can be identified on blast cells and are a combination of a myeloid marker, a normal progenitor antigen and (multiple) aberrantly expressed cell surface marker(s) [10].

Two main approaches are used for the detection of MRD by MFC: the LAIP approach, where LAIPs are defined at diagnosis and their presence subsequently monitored at followup [11]; and the different-from-normal (DfN) approach, which screens follow-up material on the presence of aberrant LAIPs, irrespective of the LAIP at diagnosis [12]. MFC-MRD is applicable and widely accessible in the majority of AML patients, and in the past decade many laboratories have gained experience in MFC analysis, making it the current gold standard to determine MRD in AML. Its sensitivity is reported to range from $10^{-3}$ to $10^{-5}$ [13]. However, accurate assessment is dependent on various factors, including the expertise of trained personnel, making it a highly subjective technique. Hence, standardized MFC data analyses are hard to implement and alternative MRD detection techniques are being explored. 


\subsection{Molecular Approaches}

The Reverse-Transcription Polymerase Chain Reaction (RT-PCR), as well as RQ-PCR, can be used for the assessment of MRD in specific subsets of AML, in particular those that harbor fusion transcripts or specific somatic mutations [14]. RQ-PCR is able to accurately quantify the abundance of these genetic aberrations by combining conventional PCR with a fluorophore measuring the amplification of the PCR-product in real time. RQ-PCR strategies generally reach relatively high sensitivities of detection, i.e., $10^{-5}-10^{-6}$ [15]; on average tenfold higher compared to MFC.

The applicability of RT/RQ-PCR is limited to a selected number of recurrent genetic changes in AML. For instance, RQ-PCR is employed for detection of the fusion genes RUNX1/RUNX1T1 and CBFB/MYH11 in core-binding factor (CBF) leukemia's characterized by a $\mathrm{t}(8 ; 21)$ chromosomal translocation or inversion of chromosome 16 , respectively [16]. Several studies have reported that molecular MRD of these fusion genes in CR after initial chemotherapy leads to an increased risk of relapse. For example, a prospective study of 278 patients concluded that MRD monitoring by quantitative RT-PCR of the CBF fusion genes can identify patients with an increased risk of relapse [17]. Similar results were found in a prospective study of 198 patients enrolled in the French-CBF 2006 trial [18], as well as in several smaller CBF-AML study cohorts $[19,20]$. Of note, screening for persistence in $\mathrm{CR}$ has not been broadly incorporated in clinical routine due to the incidence of clonal hematopoiesis $(\mathrm{CH})$, a non-malignant expansion of hematologic cells harboring specific recurrent mutations. Hence, AML patients can have low-level fusion transcripts in $\mathrm{CR}$ but never relapse, suggesting a state of $\mathrm{CH}$ rather than residual leukemia. However, reappearing or rising levels of fusion transcripts have been shown to associate with disease relapse. Identifying mutations associated with $\mathrm{CH}$ could aid in predicting subsets of AML patients less likely to relapse.

Along with the CBF-leukemia transcripts, RQ-PCR has been successfully applied to detect MRD in adult AMLs with mutations in the Nucleophosmin (NPM1) gene. NPM1 mutations are among the most frequently observed molecular lesions in AML, occurring in approximately $30 \%$ of all patients and in 50-60\% of AMLs with normal karyotypes [21]. At present, more than 55 different NPM1 mutations, generally 4 base-pair insertions, have been observed, of which three types (A, B, and D) account for circa $95 \%$ of all cases [22]. The 4 base pair-insertion mutations in NPM1 are generally stable throughout the course of disease including at time of relapse [23]. However, this may not be the case for all NPM1 mutant AML patients, since no mutant NPM1 was detectable in $9 \%$ of patients at time of relapse [24]. Succeeding the first study describing the quantitative MRD assessment of NPM1 mutant AML by RT-PCR [25], multiple additional studies have monitored NPM1 mutant MRD. More recently, RQ-PCR for NPM1 mutations in a large cohort of 346 patients demonstrated a clear association of persisting NPM1 mutations with a greater risk of relapse [26]. These results were in concordance with previous findings where NPM1 mutations persisting in $\mathrm{CR}$ were a strong prognostic marker for the development of disease relapse [24,27-31]. Of note, low levels of NPM1 mutant MRD are associated with a higher risk of relapse only in the presence of a co-occurring FLT3 internal tandem duplication (ITD) [32].

In contrast, MRD assessment of DNA MethylTransferase 3A (DNMT3A) mutations by RQ-PCR was not predictive of relapse in AML patients. In a cohort of 181 patients that harbored one of two known hotspot mutations in DNMT3A; R882H or R882C, transcript levels at multiple time-points were determined. In the majority of patients, the presence of mutant DNMT3A in CR did not result in AML relapse, indicating that mutations in $D N M T 3 A$ occur early on in leukemogenesis and that additional mutations in driver genes are required for the development of AML. Thus, hotspot mutations in DNMT3A appeared not to be a suitable target for MRD testing in AML [33].

In addition, the overexpression of certain genes can be measured by RQ-PCR and were shown to have prognostic value as MRD marker in AML. Overexpression of the Wilms Tumor 1 (WT1) gene, encoding a transcription factor often overexpressed in AML, 
is most studied in this context [34]. Several studies have applied RQ-PCR for sequential monitoring of WT1, and reported an increased risk of relapse associated with elevated WT1 levels $[35,36]$. Although molecular assays based on gene transcript levels are applicable for patients without AML-specific molecular markers, they have some limitations. For example, the sensitivity is limited by the expression of the wild type gene in the tissue of interest, leading to an estimated subset of only $13-46 \%$ of AML patients with WT1 expression high enough to serve as MRD marker [36]. In efforts to overcome this, combining quantification of WT1 with MFC led to an improved prediction of relapse [37].

Molecular MRD in adult AML may also be detected by means of digital droplet PCR (ddPCR); a digital PCR-based assay using absolute quantification of amplified target genes without the need of standard curves. The feasibility of ddPCR in detecting MRD has been tested in several studies and is eligible in particular for NPM1 mutant AML patients, [38-41]. In addition, some studies have explored the use of ddPCR for MRD detection of other leukemia-associated mutations, including in IDH1/2 [42,43] or in a subset of different mutations associated with AML [44,45]. Although these studies concluded that ddPCR is a feasible method for predicting relapse using MRD detection in AML with a relatively high limit of detection, larger cohort sizes are needed to confirm these mutations as reliable MRD markers. However, a major limitation of ddPCR is that each assay needs to be specifically designed for every acquired aberration, meaning that in contrast to recurrent mutations in AML, ddPCR would be a less efficient and more laborious approach for rare patient-specific mutations without a standardized assay.

\subsection{Next Generation Sequencing (NGS) for MRD Detection in AML}

Despite the high sensitivity of RT/RQ/dd-PCR-based assays in detecting MRD of AML carrying specific gene fusions or hotspot mutations in driver genes, their applicability is limited to only specific AML subsets due to the unavailability of robust molecular markers in the remaining AML cases. NGS provides a solution by allowing the detection of various and patient-specific gene mutations in a single assay [46]. NGS approaches make use of high-throughput sequencing techniques and refer mainly to several different modern massively parallel sequencing technologies such as WGS, WES and targeted sequencing. These approaches provide DNA sequencing data of whole genomes, whole exomes, or multiple genes, respectively, in a more efficient and less time consuming manner compared to for example Sanger sequencing [47]. Molecular MRD detection using NGS permits a comprehensive and relatively sensitive evaluation of an individuals' response to treatment, thereby providing potentially important prognostic and predictive information in AML patients. Multiple studies have been performed where detecting molecular MRD in adult AML using NGS is examined (Table 1).

Several early studies have explored the ability of applying NGS for the detection of molecular MRD, initially focusing on selected molecular markers. In 2012, MRD detection based on NPM1 mutations and FLT3-ITD mutations in 20 AML patients demonstrated that NGS can reliably assess molecular MRD status, and showed a $95 \%$ concordance with RQ-PCR for mutated NPM1 [48]. In another study, the potential of RUNX1 mutations as MRD marker was investigated using deep amplicon sequencing in a prospective cohort of 814 AML patients, with 103 patients eligible for RUNX1 paired diagnosis-remission analysis. Median residual RUNX1 mutational burden, defined as $3.61 \%$ of variants reads in follow-up, was used to assign patients to two different groups, with one group $(<3.61 \%$ mutational burden) having a significantly better outcome in terms of EFS and OS [49]. In recent years, several studies have shown that MRD detection by targeting multiple molecular markers using NGS is feasible and associates with response to therapy in AML. In 2015, an NGS-based MRD study was performed on 50 AML patients receiving standard induction chemotherapy [50]. WGS or WES was carried out on AML samples obtained at diagnosis, followed by enhanced deep exon sequencing targeting 264 recurrently mutated genes in paired AML diagnosis and CR samples. Of these patients, $48 \%$ had persistent mutations in $\mathrm{CR}$ with a variant allele frequency (VAF) of at least $2.5 \%$, and a significantly 
reduced event-free survival (EFS) and overall survival (OS). This study demonstrated that NGS-based approaches could improve risk stratification of AML patients. Besides AML patients receiving standard chemotherapy, NGS-based MRD detection has also been explored in patients who underwent hematopoietic stem cell transplantation (HSCT). Getta et al. investigated if NGS could be used for MRD detection, in this study defined as mutations present above a VAF of $5 \%$ before HSCT. Mutations detected by a panel of 28 genes at diagnosis and prior to allogeneic HSCT were compared with MRD detected by MFC [51]. A concordance of $71 \%$ between the two MRD detection assay results was demonstrated, and detectable MRD appeared to be significantly associated with an increased risk of relapse post-transplantation. Patients with MRD detectable with both assays showed the highest risk of relapse, indicating that a multi-gene NGS gene panel can provide additional clinical information compared to MFC alone [51].

In a subsequent study, targeted NGS was performed on bone marrow or peripheral blood samples of 482 AML patients obtained at diagnosis and at CR after induction chemotherapy [52]. By using a gene panel covering 54 recurrently mutated AML genes, there was at least one detectable mutation found in $89.2 \%$ of patients at diagnosis. Using the same assay for samples obtained after therapy, $51.4 \%$ of patients harbored a persistent mutation with varying rates across genes, and VAFs ranging between 0.02 and $47 \%$. The detection of a persistent mutation in CR was significantly associated with a higher incidence of relapse. Interestingly, persisting mutations in genes associated with age-related clonal hematopoiesis (CHIP); DNMT3A, TET2, ASXL1 (DTA), were among the most common, and were frequently present at a relatively high VAF. Patients with only DTA mutations persisting in CR were significantly less likely to develop a relapse, whereas patients that harbored a persisting mutation in other genes than DTA were associated with an increased risk of relapse, a reduced relapse free survival (RFS), and a reduced OS, also in multivariable analyses [52].

Around the same time, Morita et al. [53] investigated whether MRD status in CR could predict an impending relapse in a cohort of 131 AML patients. A gene panel consisting of 295 genes was used to evaluate mutations in pre-treatment samples, revealing at least one mutation in $93 \%$ of patients. BM samples of patients that reached CR at 30 days post induction chemotherapy were sequenced. Different VAF cut-offs $(2.5 \%, 1.0 \%$, and undetectable) were used to examine the association between clinical outcome and clearance of mutation after therapy. Persistent mutations with VAF $<1 \%$ were associated with a substantial better OS compared to patients with higher VAFs. Patients with no detectable mutations post-therapy showed significantly better EFS [53]. These prognostic associations were stronger when cases were excluded with persisting mutations in DTA genes only.

In another study of 104 AML patients receiving allogeneic HSCT, MRD was assessed pre- and post-HSCT [54]. A panel targeting 84 genes was used on samples obtained at diagnosis, pre- and post-HSCT. At diagnosis, $86.5 \%$ of patients harbored at least one mutation. Mutation clearance was found in $44.5 \%$ of patients pre-HSCT, with a further reduction after transplantation. Although patients with a VAF of $2 \%$ at pre-HSCT had a worse OS, no association was found with relapse incidence. Bone marrow samples were collected 21 days after transplantation and sequenced utilizing a computational error correction approach, with a cut-off of $0.2 \%$ VAF. Detection of MRD post-HSCT was significantly associated with an increased risk of relapse and a decreased OS compared to AML patients with undetectable MRD [54].

The use of a high-sensitivity targeted NGS-based MRD detection assay was again investigated by using a gene panel covering 46 genes on 116 pre-HSCT AML patient samples [55]. In this analysis at least one potential MRD marker was found in $93 \%$ of AML cases. Of these patients, $45 \%$ were found to have detectable persisting mutations with a median VAF of $0.33 \%$. In order to increase the sensitivity, error-corrected sequencing (ECS) with unique molecular indices (UMIs) was applied, enabling detection with a sensitivity 
of $<0.02 \%$. Residual molecular MRD measured at CR was found to be an independent predictor of relapse and survival by multivariate analysis [55].

In a similar, retrospective study, 42 AML patients were sequenced using a 42 gene panel at diagnosis, and before allogeneic HSCT time points. With a relatively high limit of detection of $0.5 \%$, persistent mutations in pre-transplant samples were found to be a significant predictor of leukemic relapse and survival [56].

In 2019, Balagopal et al. explored a hybrid-capture error-corrected NGS method with the incorporation of UMIs on post-HSCT samples that were previously evaluated as negative by engraftment studies. By utilizing the UMIs, mutations at a VAF of $<0.1 \%$ could be reliably detected in 22 frequently mutated genes in AML. With this improved sensitivity, previously undetected residual mutations associated with an eventual relapse were found in 18 out of 30 AML patients [57].

Hourigan and colleagues [58] examined blood samples from a cohort of 190 pretransplant AML patients who reached morphologic CR and received allogeneic HSCT. In this study, the clinical impact of myeloblative conditioning (MAC) or reduced intensity conditioning (RIC) regimens for AML patients with molecular MRD in preconditioning blood before transplantation was investigated. Ultra-deep ECS was performed for 13 commonly mutated genes in AML, and patients were randomly allocated to either MAC or RIC. DTA mutations were among the most commonly detected in this study but had limited prognostic value. For AML patients with a detectable non-DTA mutation pre-transplant, they observed significant differences in relapse rates (19\% vs. $67 \%$; $p<$ $0.001)$ and OS (61\% vs. $43 \% ; p=0.02)$ between patients with MAC or RIC, respectively. This study provides evidence that MAC may result in highly improved outcome for AML patients with pre-transplant molecular MRD [58].

More recently, Heuser et al. [59] assessed whether MRD monitoring of non-DTA mutations would be of prognostic value regarding relapse and overall survival in postallogeneic HSCT AML patients. In a cohort of 154 AML patients, 138 had a mutation present at diagnosis (90\%). Using an error-corrected based NGS assay, residual disease was detected in $25 \%$. In AML patients harboring residual DTA mutations no effect was observed on relapse- and survival rates. In contrast, the presence of MRD defined by non-DTA mutations was found to be an adverse predictor for both relapse and survival, indicating that MRD defined by non-DTA mutations is of prognostic value for post-allogeneic HSCT patients [59].

In another recent study [60], a targeted NGS approach in 335 AML patients was used to assess MRD at two different time points: in CR and after consolidation therapy. A total of 54 genes associated with AML was studied with the exception of mutations in DTA, CEBPA and FLT3-ITD, due to either their association with CH (DTA) or limited sequencing sensitivity (CEBPA and FLT3-ITD). Detectable MRD was defined as variants with a VAF higher than 2 standard deviations from the mean background error, and was detectable in $46.4 \%$ of AML patients in CR and $28.9 \%$ after consolidation. MRD at both time points was associated with an increased incidence of relapse, as well as decreased OS, also in multivariate analysis. The prognostic impact of detectable MRD after first consolidation therapy was higher compared to that in CR. AML patients without persisting mutations only after consolidation had similar outcomes as patients without MRD before and after consolidation. [60].

Recent assessment of molecular MRD in a study including 132 AML patients undergoing allogeneic-HSCT revealed prognostic value of persistent mutations at both pre- and post-HSCT. The presence of any persistent mutation was associated with a higher risk of relapse and decreased OS. In contrast to previous findings, persistence of isolated DTA mutations in CR was also associated with post-transplant relapse [61].

The suitability of DTA mutations as MRD marker in AML was further evaluated in a recent study including 68 AML patients harboring at least one mutation in DTA genes at diagnosis. No association was found between persisting DTA mutations in CR before HSCT and relapse or OS. Interestingly, when hotspot mutations in DNMT3A (R882) and 
ASXL1 (G646fs*12) were excluded, the remaining AML patients appeared to have a worse clinical outcome. As opposed to previous findings, these results may indicate that specific non-canonical mutations in DTA genes could be suitable MRD markers in AML [62]. Larger AML cohorts will be needed to confirm these findings.

The impact of $\mathrm{CH}$-associated mutations in AML patients harboring an NPM1 mutation has recently been studied in a retrospective cohort of $150 \mathrm{AML}$ patients [63]. In addition to aberrations in DTA genes, mutations in SRSF2, IDH1 and IDH2 were defined as mutations associated with $\mathrm{CH}$. Persistence of these mutations in $\mathrm{CR}$ was shown not to be associated with worse EFS and OS, which indicates that these mutations represent a pre-malignant state where the acquisition of additional mutations is needed for the development of AML, similar to what has been proposed for DTA mutations [52], and that the acquisition of NPM1 mutations is a later event in the formation of leukemia [63].

\subsection{Combining NGS and MCF for MRD Detection}

Currently, the gold standard in MRD testing is MFC. While both immunophenotypic and molecular techniques have their own principles, and therefore their own limitations, limited studies are published where multiple methods were applied and compared $[51,64,65]$. Studies comparing NGS and MFC in 62 and 340 patients showed that the two techniques had an overall concordance of $\sim 70 \%$ [51,52]. Moreover, patients with detectable MRD by both assays had the highest risk of relapse. A discordance was seen in a fraction of 64/340 (19\%) of AML patients with detectable MRD by NGS only, and for $41 / 340(12 \%)$ of patients with detectable MRD by MFC only. Interestingly, AML patients with discordant results between NGS and MFC had worse outcomes compared to patients without detectable MRD by both techniques [52].

Table 1. Next Generation Sequencing Studies for MRD Detection in adult AML.

\begin{tabular}{|c|c|c|c|c|c|c|c|}
\hline Author & Year & NGS Approach & $\begin{array}{l}\text { Cohort } \\
\text { Size }(n)\end{array}$ & $\begin{array}{c}\text { Mean } \\
\text { Coverage }\end{array}$ & $\begin{array}{l}\text { Threshold } \\
\text { MRD } \\
\text { (VAF) }\end{array}$ & $\begin{array}{c}\text { MRD } \\
\text { Mutations }\end{array}$ & Key Finding \\
\hline $\begin{array}{l}\text { Thol } \\
{[48]}\end{array}$ & 2012 & $\begin{array}{l}\text { Amplicon } \\
\text { sequencing of } \\
\text { NPM1 and } \\
\text { FLT3-ITD } \\
\text { mutations }\end{array}$ & 20 & $\begin{array}{l}7758 \times \\
\text { NPM1) } \\
15,278 \\
(\text { FLT3) }\end{array}$ & $\begin{array}{l}0.29 \text { for } \\
\text { NPM1 } \\
\text { (allelic } \\
\text { ratio) }\end{array}$ & $\begin{array}{l}\text { NPM1 and } \\
\text { FLT3-ITD }\end{array}$ & $\begin{array}{c}\text { Using NGS, MRD can reliably } \\
\text { be assessed for NPM1 } \\
\text { mutations. FLT3-ITD clones } \\
\text { can be assessed in one single } \\
\text { assay }\end{array}$ \\
\hline $\begin{array}{l}\text { Kohlmann } \\
\text { [49] }\end{array}$ & 2014 & $\begin{array}{l}\text { Amplicon deep } \\
\text { sequencing of } \\
\text { RUNX1 }\end{array}$ & 103 & $844 \times$ & $1 \%$ & RUNX1 & $\begin{array}{c}\text { Detection of residual RUNX1 } \\
\text { can distinguish distinct risk } \\
\text { groups based on mutational } \\
\text { load }\end{array}$ \\
\hline $\begin{array}{l}\text { Klco } \\
{[50]}\end{array}$ & 2015 & $\begin{array}{c}\text { WES or } \\
\text { WGS at } \\
\text { diagnosis, } \\
\text { followed by deep } \\
\text { exon sequencing } \\
\text { of } 264 \text { recurrently } \\
\text { mutated genes in } \\
\text { AML }\end{array}$ & 50 & $\begin{array}{l}543 \times \text { or } \\
14,780 \times\end{array}$ & $5 \%$ & $\begin{array}{l}13 \\
\text { recurrently } \\
\text { mutated } \\
\text { genes in } \\
\text { AML }\end{array}$ & $\begin{array}{c}\text { Detection of residual } \\
\text { mutations associated with } \\
\text { AML correlate with increased } \\
\text { risk of relapse and decreased } \\
\text { OS }\end{array}$ \\
\hline $\begin{array}{c}\text { Getta } \\
\text { [51] }\end{array}$ & 2017 & $\begin{array}{c}\text { Targeted } \\
\text { sequencing using } \\
\text { a 28-gene } \\
\text { amplicon } \\
\text { capture-based } \\
\text { panel }\end{array}$ & 104 & Unknown & $5 \%$ & $\begin{array}{l}28 \\
\text { recurrently } \\
\text { mutated } \\
\text { genes in } \\
\text { AML }\end{array}$ & $\begin{array}{c}\text { MRD can be detected by NGS } \\
\text { using a multi-gene panel } \\
\text { before allogeneic HSCT. } \\
\text { Detection of MRD by both } \\
\text { MFC and NGS was associated } \\
\text { with the highest risk of } \\
\text { relapse }\end{array}$ \\
\hline $\begin{array}{l}\text { Jongen- } \\
\text { Lavrencic } \\
\text { [52] }\end{array}$ & 2018 & $\begin{array}{c}\text { Targeted } \\
\text { sequencing using } \\
\text { a 54-gene NGS } \\
\text { panel }\end{array}$ & 482 & $3500 \times$ & $0.02 \%$ & $\begin{array}{l}\text { non-DTA, } \\
\text { persistent } \\
\text { mutations } \\
\text { found in } 27 \\
\text { genes }\end{array}$ & $\begin{array}{c}\text { Detection of persisent } \\
\text { mutations in CR associated } \\
\text { with } \mathrm{CH}(D T A) \text { did not } \\
\text { correlate with an increased } \\
\text { risk of relapse }\end{array}$ \\
\hline
\end{tabular}


Table 1. Cont.

\begin{tabular}{|c|c|c|c|c|c|c|c|}
\hline Author & Year & NGS Approach & $\begin{array}{l}\text { Cohort } \\
\text { Size }(n)\end{array}$ & $\begin{array}{l}\text { Mean } \\
\text { Coverage }\end{array}$ & $\begin{array}{l}\text { Threshold } \\
\text { MRD } \\
\text { (VAF) }\end{array}$ & $\begin{array}{c}\text { MRD } \\
\text { Mutations }\end{array}$ & Key Finding \\
\hline $\begin{array}{c}\text { Morita } \\
\text { [53] }\end{array}$ & 2018 & $\begin{array}{c}\text { Targeted } \\
\text { capture-based } \\
\text { deep sequencing } \\
\text { using a } 295 \text { gene } \\
\text { panel }\end{array}$ & 131 & $575 \times$ & $1.0 \%$ & $\begin{array}{l}35 \\
\text { Recurrently } \\
\text { mutated } \\
\text { genes in } \\
\text { AML/non- } \\
\text { DTA } \\
\text { mutations }\end{array}$ & $\begin{array}{c}\text { Detection of persistent } \\
\text { mutations at day } 30 \text { after } \\
\text { treatment with low VAF } \\
(<1 \%) \text { was associated with } \\
\text { improved EFS and OS. } \\
\text { This was enhanced when DTA } \\
\text { mutations were removed } \\
\text { from the analysis }\end{array}$ \\
\hline $\begin{array}{l}\text { Kim } \\
{[54]}\end{array}$ & 2018 & $\begin{array}{l}\text { Targeted } \\
\text { sequencing using } \\
\text { a } 84 \text { gene NGS } \\
\text { panel }\end{array}$ & 104 & $1725.6 \times$ & $0.02 \%$ & $\begin{array}{l}\text { Persistent } \\
\text { mutations in } \\
\text { unknown } \\
\text { number of } \\
\text { commonly } \\
\text { mutated } \\
\text { genes in } \\
\text { AML }\end{array}$ & $\begin{array}{c}\text { Detection of MRD at } 21 \text { days } \\
\text { post-HSCT was associated } \\
\text { with an increased risk of } \\
\text { relapse and decreased OS }\end{array}$ \\
\hline $\begin{array}{l}\text { Thol } \\
\text { [55] }\end{array}$ & 2018 & $\begin{array}{l}\text { Targeted } \\
\text { sequencing using } \\
\text { a } 46 \text { gene NGS } \\
\text { custom amplicon } \\
\text { panel with } \\
\text { UMI-based ECS }\end{array}$ & 116 & $6,100 \times$ & $0.016 \%$ & $\begin{array}{c}24 \\
\text { Recurrently } \\
\text { mutated } \\
\text { genes in } \\
\text { AML, NPM1 } \\
\text { and } \\
\text { DNMT3A } \\
\text { were } \\
\text { excluded }\end{array}$ & $\begin{array}{c}\text { Detection of MRD using NGS } \\
\text { with UMI-based ECS before } \\
\text { allogeneic HSCT is predictive } \\
\text { for relapse and OS }\end{array}$ \\
\hline $\begin{array}{c}\text { Press } \\
{[56]}\end{array}$ & 2019 & $\begin{array}{l}\text { Targeted } \\
\text { sequencing of a } \\
42 \text { custom gene } \\
\text { panel, including } \\
\text { recurrently } \\
\text { mutated genes in } \\
\text { AML }\end{array}$ & 42 & $1900 \times$ & $0.50 \%$ & $\begin{array}{l}16 \\
\text { recurrently } \\
\text { mutated } \\
\text { genes in } \\
\text { AML }\end{array}$ & $\begin{array}{l}\text { Detection of MRD in } \\
\text { pre-HSCT is significant } \\
\text { predictor for relapse and OS }\end{array}$ \\
\hline $\begin{array}{c}\text { Balagopal } \\
\text { [57] }\end{array}$ & 2019 & $\begin{array}{l}\text { Targeted } \\
\text { capture-based } \\
\text { sequencing using } \\
\text { a } 22 \text { gene NGS } \\
\text { panel with } \\
\text { UMI-based ECS }\end{array}$ & 30 & $10,000 \times$ & $0.1 \%$ & $\begin{array}{l}12 \\
\text { recurrently } \\
\text { mutated } \\
\text { genes in } \\
\text { AML }\end{array}$ & $\begin{array}{l}\text { The inclusion of UMIs allows } \\
\text { for a highly sensitive MRD } \\
\text { detection, effective in } \\
\text { predicting a relapse at } \\
\text { post-HSCT in AML patients }\end{array}$ \\
\hline $\begin{array}{c}\text { Hourigan } \\
\text { [58] }\end{array}$ & 2020 & $\begin{array}{c}\text { Targeted } \\
\text { ultra-deep } \\
\text { sequencing of } 13 \\
\text { commonly } \\
\text { mutated genes in } \\
\text { AML, } \\
\text { with UMI-based } \\
\text { ECS on PB } \\
\text { samples }\end{array}$ & 190 & $41 \times 10^{6}$ & $0.001 \%$ & $\begin{array}{l}13 \\
\text { recurrently } \\
\text { mutated } \\
\text { genes in } \\
\text { AML / } \\
\text { non-DTA }\end{array}$ & $\begin{array}{l}\text { MRD detection in AML } \\
\text { patients pre-HSCT who } \\
\text { underwent myeloblative } \\
\text { conditioning had lower } \\
\text { relapse rates and higher OS } \\
\text { compared to patients } \\
\text { undergoing reduced intensity } \\
\text { conditioning regimens. } \\
\text { DTA mutations had no } \\
\text { prognostic value }\end{array}$ \\
\hline $\begin{array}{c}\text { Heuser } \\
\text { [59] }\end{array}$ & 2021 & $\begin{array}{l}\text { Amplicon based } \\
\text { ECS for } 46 \\
\text { commonly } \\
\text { mutated genes in } \\
\text { AML }\end{array}$ & 154 & $526,161 \times$ & $0.048 \%$ & $\begin{array}{l}\text { non-DTA } \\
\text { mutations } \\
\text { included in } \\
\text { panel }\end{array}$ & $\begin{array}{c}\text { Detection of residual } \\
\text { non-DTA mutations was } \\
\text { highly predictive for relapse } \\
\text { and associated with decreased } \\
\text { OS in multivariate analysis for } \\
\text { post-allogeneic HSCT AML } \\
\text { patients }\end{array}$ \\
\hline
\end{tabular}


Table 1. Cont.

\begin{tabular}{|c|c|c|c|c|c|c|c|}
\hline Author & Year & NGS Approach & $\begin{array}{l}\text { Cohort } \\
\text { Size }(n)\end{array}$ & $\begin{array}{c}\text { Mean } \\
\text { Coverage }\end{array}$ & $\begin{array}{l}\text { Threshold } \\
\text { MRD } \\
\text { (VAF) }\end{array}$ & $\begin{array}{c}\text { MRD } \\
\text { Mutations }\end{array}$ & Key Finding \\
\hline $\begin{array}{l}\text { Tsai } \\
{[60]}\end{array}$ & 2021 & $\begin{array}{c}\text { Targeted } \\
\text { sequencing of } 54 \\
\text { genes associated } \\
\text { with AML at } \\
\text { diagnosis, CR, } \\
\text { and after } \\
\text { consolidation } \\
\text { chemotherapy }\end{array}$ & 335 & $10,550 \times$ & $0.3 \%$ & $\begin{array}{l}42 \text { non-DTA } \\
\text { mutations } \\
\text { included in } \\
\text { panel (except } \\
\text { for CEBPA } \\
\text { and } \\
\text { FLT3-ITD) }\end{array}$ & $\begin{array}{l}\text { Detection of residual non-DTA } \\
\text { mutations after consolidation } \\
\text { therapy has more prognostic } \\
\text { value than detection after } \\
\text { induction therapy }\end{array}$ \\
\hline $\begin{array}{l}\text { Kim } \\
{[61]}\end{array}$ & 2021 & $\begin{array}{l}\text { Amplicon-based } \\
\text { sequencing of } 67 \\
\text { genes in a } \\
\text { custom NGS } \\
\text { panel at three } \\
\text { timepoints } \\
\text { (diagnosis, } \\
\text { pre-HSCT, } \\
\text { post-HSCT) }\end{array}$ & 132 & $2406 \times$ & $0.01 \%$ & $\begin{array}{l}\text { All mutations } \\
\text { included in } \\
\text { panel, DTA } \\
\text { and CHIP } \\
\text { mutations at } \\
\text { pre-HSCT }\end{array}$ & $\begin{array}{c}\text { Persistent DTA and } \\
\text { CHIP-associated mutations at } \\
\text { pre-HSCT are associated with } \\
\text { increased risk of relapse } \\
\text { post-HSCT }\end{array}$ \\
\hline $\begin{array}{c}\text { Jentzsch } \\
\text { [62] }\end{array}$ & 2021 & $\begin{array}{l}\text { Targeted } \\
\text { amplicon } \\
\text { sequencing of } \\
\text { DNMT3A and } \\
\text { ASXL1 }\end{array}$ & 68 & Unknown & $0.0001 \%$ & $\begin{array}{l}\text { Canonical } \\
\text { mutations in } \\
\text { DTA: } \\
\text { DNMT3A } \\
\text { (R882) and } \\
\text { ASXL1 } \\
(\text { G646fs*12) }\end{array}$ & $\begin{array}{l}\text { Exclusion of detection of } \\
\text { residual hotspot mutations in } \\
D N M T 3 A(\mathrm{R} 882) \text { and } A S X L 1 \\
\left(\mathrm{G} 646 \mathrm{fs}{ }^{*} 12\right), \text { leads to a worse } \\
\text { clinical outcome in AML } \\
\text { patients }\end{array}$ \\
\hline $\begin{array}{c}\text { Cappelli } \\
\text { [63] }\end{array}$ & 2021 & $\begin{array}{c}\text { Targeted } \\
\text { sequencing of } 63 \\
\text { genes associated } \\
\text { with hematologic } \\
\text { malignancy at } \\
\text { diagnosis, CR, } \\
\text { and relapse, } \\
\text { validation using } \\
\text { WGS }\end{array}$ & 150 & $\begin{array}{l}\text { Unknown } \\
\text { for panel } \\
\text { sequencing, } \\
100 \times \text { for } \\
\text { WGS }\end{array}$ & $1 \%$ & $\begin{array}{l}\text { non-DTA- } \\
\text { SRSF2 } \\
\text {-IDH1/2 } \\
\text { (CHOP-like } \\
\text { mutations) }\end{array}$ & $\begin{array}{c}\text { In addition to DTA, mutations } \\
\text { in } S R S F 2, I D H 1 \text {, and IDH2 } \\
\text { were not associated with a } \\
\text { worse prognosis in NPM1 } \\
\text { mutated AMLs }\end{array}$ \\
\hline $\begin{array}{c}\text { Patkar } \\
{[66]}\end{array}$ & 2021 & $\begin{array}{l}\text { Capture-based } \\
\text { sequencing of } 34 \\
\text { genes using a } \\
\text { custom NGS } \\
\text { panel with the } \\
\text { inclusion of } \\
\text { UMI-based ECS }\end{array}$ & 201 & $14,728 \times$ & $0.05 \%$ & $\begin{array}{l}\text { NPM1, FLT3, } \\
\text { NRAS, KIT, } \\
\text { IDH1/2, WT1, } \\
\text { RUNX1, } \\
\text { GATA2, } \\
\text { U2AF1, PHF6 }\end{array}$ & $\begin{array}{l}\text { Panel-based ECS is highly } \\
\text { concordant with MFC } \\
\text { techniques for the detection of } \\
\text { MRD }\end{array}$ \\
\hline
\end{tabular}

Note: Adjusted and supplemented from Yoest et al. [46].

More recently, Patkar et al. [66] evaluated MRD in 201 AML patients by both techniques after induction- and consolidation therapy. For NGS, the limit of detection was a VAF of $0.05 \%$, and detection of MRD was significantly associated with inferior outcome for both time points. Detection of MRD by NGS was equivalent to MFC in $>80 \%$ of patients, with discrepancies in only a fraction of AML patients, where prediction of outcome with MRD by NGS seemed to be superior to those with MRD by MFC [66].

\section{Challenges Related to MRD Detection by NGS}

\subsection{Sensitivity \& Specificity}

The most challenging limiting factors in AML MRD detection by NGS are the sensitivity and specificity of the sequencing assays. Due to intrinsic properties of the sequencing devices such as cross-talk between clusters and phasing effects [67], or during PCR amplification at the library preparation stage, errors are introduced that influence the ultimate 
low-level base calling by NGS. Whereas in usual clinical settings, NGS can be reliably used to detect disease-specific mutations with VAFs of $>1 \%$, MRD applications generally desire detection of VAFs in the range of $0.01-0.5 \%$. Most sequencing devices harbor an error rate of approximately $1 \%$, meaning that the limit of detection for MRD applications could clearly pose a problem [68]. Of note, sensitivity issues for MRD detection can be mutation specific. For example, insertions in NPM1 and FLT3-ITDs are easily discriminated from noise and can be detected at low levels. However, low-level detection of persistent NPM1 mutations may not directly associate with increased risk of AML relapse [24,32], whereas late transforming events, such as mutations in FLT3 may associate when detected at low level.

In order to overcome possible issues with sequencing error rates, ECS methods have been introduced. This approach incorporates unique molecular identifiers (UMIs) to the DNA targets during library preparation [68]. These UMIs are short sequences ( 3-16 nucleotides) that are used to trail back the original molecular input. Incorporation of UMIs allows for the differentiation between sequencing errors and true mutations in the variant reads produced during the sequencing process. The UMIs are incorporated during the early stages of the library preparation to minimize the effect of errors produced in the initial PCR cycles, while also enabling the removal of PCR duplicates. After sequencing, the resulting reads are grouped based on identical UMI sequences into read families. A variant that is present in all reads within a read family indicates a true mutation, whereas if this variant is only present in a subset of the reads, the variation was presumably caused by a sequencing error [46].

The incorporation of UMIs in the genomic DNA as a form of error-correction for the detection of MRD in AML has been put successfully into practice before in a wide variety of studies, such as in the previously mentioned studies by Thol et al. and Balagopal et al. [55,57]. For practical applications different commercial UMI-guided NGS panels are available, such as ArcherDx, smMIPS, New England BioLabs NEBNext Direct, and xGen Dual Index UMI, among others. Although these panels use a similar approach, they can differ in size of UMIs and whether single or double (duplex UMI) DNA strands are tagged with UMIs. While duplex UMI NGS methods result in a reduced error rate, higher sequencing coverage and costs are required, which makes it currently less appealing to implement duplex UMI NGS methods for clinical use [46]. Alternatively, ECS can be achieved by using biochemical or computational approaches. Biochemically, a proofreading polymerase enables a last verification step to check whether the right nucleotide is incorporated before synthesis [69]. Computationally, sequencing reads with low quality and mapping scores can be removed since they indicate a high error rate, or a background error model can be used to determine statistically if a variant is expected to be caused by a sequencing artifact or not [70].

Next to intrinsic sequencing errors, the event of index hopping can negatively influence the downstream analysis of NGS MRD detection, which can occur as a result of multiplexing samples in a single NGS run. Index hopping refers to the contamination of prepared libraries with similar index sequences, resulting in the miss-assignment of reads to samples or patients. Index hopping rates were found to be between 0.2 and $6 \%$, depending on the type of library preparation [71], which would obviously affect MRD detection. A solution to this particular problem is the use of non-redundant dual indexing during library preparation, allowing for the ability to filter reads with unexpected index combinations [71,72].

\subsection{Distinguishing Leukemia from Clonal Hematopoiesis}

An obstacle in current molecular MRD approaches is to find the molecular variants that represent and are specific to leukemic cells with the capability to relapse. In addition to mutations driving the leukemia and subsequent relapse, hematopoietic cells can acquire somatic mutations that result in a proliferative advantage in the absence of a hematological malignancy [73] (Figure 1). This clonal expansion of hematopoietic cells arising from one 
HSC is of particular interest in molecular MRD testing, since the most common mutations associated with $\mathrm{CH}$ are also found in leukemia progenitor cells in patients with AML and Myelodysplastic Syndrome (MDS) [74].

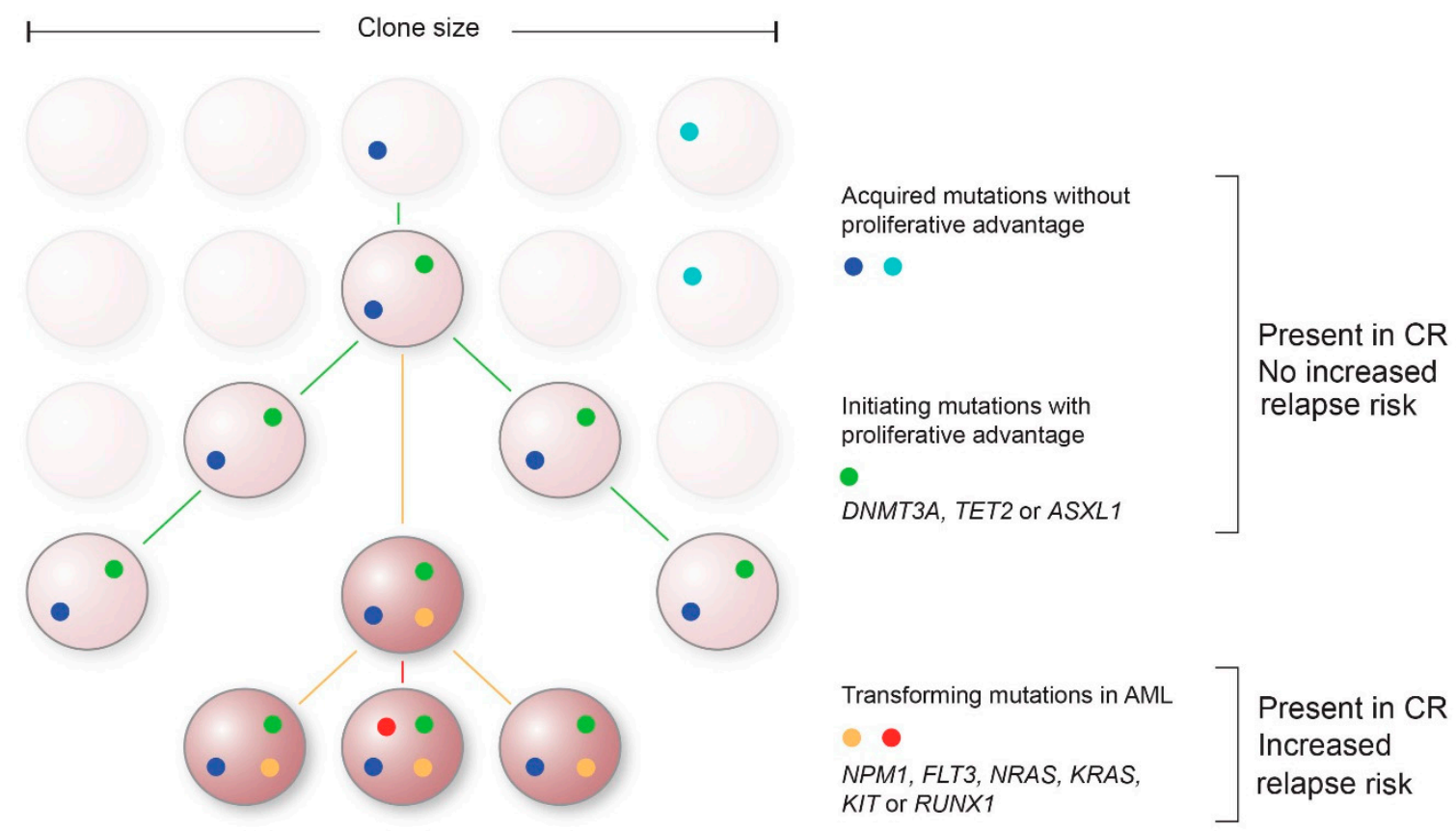

Figure 1. Proposed model of acquisition of mutations over time and their contribution to AML. Mutations without proliferative advantage will occur over time in hematopoietic progenitor cells ((light)blue) that do not contribute to leukemogenesis. Subsequently, initiating clonal hematopoiesis-associated mutations with proliferative advantage can arise, such as mutations in DNMT3A, TET2 and ASXL1 (DTA) (green). These mutations when persisting in complete remission (CR) typically do not show an association with an increased risk of relapse. Late event mutations in genes such as NPM1, FLT3, NRAS, KRAS, KIT, or RUNX1 are representative for transformation to AML (non-DTA mutations, red/yellow). Persistence of these non-DTA mutations in CR are associated with an increased risk of relapse.

Although $\mathrm{CH}$ can be a precursor state of leukemia, it is not classified itself as a hematological disorder. The main risk factor for developing $\mathrm{CH}$ is aging, with an incidence in the general population of $10-15 \%$ in people aged 70 or older and $30 \%$ at the age of 85 [73]. Persistence of somatic mutations occurring in the DNMT3A, TET2 and ASXL1 genes was found to be indicative of a state of $\mathrm{CH}$ rather than residual leukemia posttherapy $[52,58,59]$. Whether persistence of mutations in other genes in age-related $\mathrm{CH}$, such as JAK2, SF3B1, SRSF2, PPM1D, CBL, IDH1 and IDH2, are associated with an increased relapse risk is currently unknown due to the relative low incidence of these mutations in AML. Enlarging the AML cohorts could bypass this problem. Recently, Cappelli et al. revealed that mutations in SRSF2, IDH1 and IDH2 in CR represented a state of $\mathrm{CH}$ in mutant NPM1 AML without any association to increased risk of relapse [63]. Another option is to analyze the presence and VAF of mutations at multiple time points, where persistent mutations at constant VAF levels in CR might indicate a state of $\mathrm{CH}$ rather than residual leukemia.

In addition, the order in which mutations arise might be of interest in distinguishing leukemia from $\mathrm{CH}$ (Figure 1). The first acquired mutations are not necessarily the ones that cause the AML relapse, but may represent a state of $\mathrm{CH}$. Additional mutations are then required to drive the transition from a pre-malignant state to AML. For example, mutations in DNMT3A are often acquired early in AML evolution, but are not sufficient to develop leukemia [75]. Additional mutations in genes such as NPM1, FLT3, or RAS are needed for these cells to transform and become oncogenic. Analyses of the VAFs of sequentially acquired mutations provide information of the clonal evolution in AML; mutations with a higher VAF are likely to have been acquired prior to mutations with a 
lower VAF. Therefore, molecular MRD testing should be aimed at these later mutational events, since they are more likely to represent residual disease. Improved prior recognition of these late event mutations can lead to smaller and more efficient gene panels, thereby enabling the possibility for deeper sequencing with increased sensitivity.

\subsection{NGS Design Challenges}

AMLs harbor on average 13 mutations per exome, while only a subset of these mutations occur in genes recurrently mutated (Cancer Genome Atlas Research Network, 2013). Designing NGS assays that are able to detect all, often patient specific, mutations can therefore be challenging. One method to improve this, is to increase the width of the assay by performing WGS or WES sequencing at AML diagnosis. This enables the detection of a broad range of genomic aberrations including point mutations, insertions/deletions (indels), copy number variations (CNVs) and structural rearrangements of the entire genome or exome in a single run. Although these NGS-based approaches could detect all possible variants, there are currently several limitations to prevent their use for routine MRD testing. Both WGS and WES have a relatively low sensitivity compared to targeted sequencing, and the number of samples to be sequenced in a single run is limited while the data sets are substantial, making them more expensive to use in clinical practice. However, for NGS-based MRD detection, WGS with a relatively low coverage could potentially be utilized to increase the number of targets, facilitating the distinction of residual mutations from noise, thereby potentially increasing the sensitivity of the assay $\left(10^{-5}\right)$ [76].

An alternative to WGS or WES is targeted sequencing where only a fixed set of genes is being analyzed. This approach reduces sequencing costs and allows sequencing at a higher sensitivity. However, data will be limited to specific genes, and novel gene mutations may be missed. Furthermore, sequencing of two frequently mutated genes in AML; CEBPA mutations and FLT3-ITDs by using targeted gene panels is challenging for different reasons. CEBPA is a GC-rich single exon gene, making it difficult to amplify using PCR and sequence. FLT3-ITD mutations, on the other hand, can vary greatly in position and length, with insertions ranging from 3 to 400 basepairs, making it challenging to align the reads to a reference genome. Of note, an open-source analysis program called GetITD does enable high-quality alignment of NGS reads to wild type FLT3 resulting in an improved identification of insertions [77].

\subsection{Epigenetics}

A major limitation of conventional targeted NGS for low-level disease detection is a maximum level of depth that can be reached to effectively distinguish mutations with low VAFs from background noise [76]. A possibly more efficient method is to look at broader patterns specific to AML, which require a lower level of sensitivity to still enable detection of MRD [76]. In this aspect, an interesting approach is to look at epigenetic changes specific to AML, such as DNA methylation patterns, which are often more robust and widespread across the genome.

Methylation is one of the most studied epigenetic mechanisms, and is involved in multiple biological processes, including regulation of gene expression. An aberrant methylation pattern can result in inhibition or activation of genes and can ultimately contribute to the formation of tumors [78]. In contrast to point mutations, alterations in methylation occur more often in clusters; at $\mathrm{CpG}$ islands, i.e., regions rich with $\mathrm{CpG}$ dinucleotides, which are often located near the promoter region of a gene. Detection of methylation by NGS requires a distinction between methylated and non-methylated cytosine molecules. By using an enzyme-based or a bisulfite conversion kit, methylated cytosines are transformed into uracils, which will eventually be read as thymines after sequencing. The detection of these aberrant methylation patterns in tumor tissues enables a better distinction of tumor from normal tissue in comparison to NGS MRD-based assays on single base-pair substitutions. 
Aberrant DNA methylation patterns have been observed in AML patients with mutations in IDH1, IDH2 and TET2, where differentially methylated regions (DMRs) were found in 45 genes [79]. All DMRs were hyper-methylated, indicating a specific epigenetic signature in AML patients harboring these mutations [79]. In an MRD setting, a limited number of studies focusing on methylation patterns have been documented. In 2007, a study found that the presence of different methylation patterns in CR in $p 15$ and $E R \alpha$ was associated with a higher risk of relapse [80]. More recently, four aberrantly methylated CPG sites in AML were studied, but the clinical relevance for MRD detection was not established [81].

\subsection{Sampling of DNA: Peripheral Blood versus Bone Marrow}

The most common and relevant source for MRD detection in AML is the bone marrow. However, since the procedure for extracting material is much more invasive for patients, DNA derived from peripheral blood (PB) should be considered as an attractive alternative, particularly for sequential monitoring. Nowadays, the majority of clinical studies on the impact of MRD in AML are based on BM samples since this provides an increased sensitivity of approximately 1-log in detecting MRD levels compared to PB. Besides, PB is not yet recommended in the ELN2017 guidelines as source for MRD testing [9]. Nevertheless, several studies have explored its use as input for the detection of residual disease.

In 2005 already, the use of PB as input was first tested by RUNX1-RUNX1T1 RQ-PCR in AML patients with a $t(8 ; 21)$ translocation. When comparing $B M$ and $P B$ samples, a similar sensitivity was found, indicating that $\mathrm{PB}$ is a suitable source for the detection of MRD in these patients [82]. However, in a large cohort study of CBF-AML, it was shown that the assays on PB DNA did not detect MRD as efficiently as to those on BM with up to $40 \%$ of patients showing detectable MRD in BM but undetectable in PB [17]. In addition, Ivey et al. (2016) monitored mutant NPM1 levels in both BM and PB samples obtained after each cycle of chemotherapy from 346 patients with NPM1-mutated AML. They demonstrated that prediction of survival was more effective in PB samples, suggesting that the right source of MRD assessment can be dependent on the type of assay, regimen, and time point [26]. In parallel, PB-MRD assays have been analyzed using MFC. An early study in 50 AML patients using MFC found a significant concordance between BM and PB MRD levels after induction and consolidation therapy, indicating that assessing MRD status with PB can provide prognostic information [83]. Similar results were observed in a larger cohort of 114 AML patients, where paired BM and PB samples were tested for the presence of MRD by MFC. Although the sensitivity was higher in BM samples, PB samples had a higher specificity [84]. More recently, MRD was assessed in BM and PB samples of 209 AML patients. In $83 \%$ of patients with detectable MRD in BM samples, the use of PB samples led to detectable MRD as well, indicating a strong concordance between the two. Nonetheless, although PB allows for serial monitoring, BM is currently still the advised input source for MFC-MRD testing due to its higher sensitivity [85].

In addition to PCR- and MFC-based assays, several studies have looked into the use of PB in NGS-based methods. In a retrospective analysis of NGS-based MRD with serial PB and BM samples of 12 AML and 8 MDS patients after HSCT, similar results were obtained with $\mathrm{PB}$ and $\mathrm{BM}$ suggesting that both could be used for NGS-based MRD in AML. However, the size of this AML cohort was limited, and confirmation using larger sample sizes is needed [86]. Contrarily, in another study, discrepancies in leukemic driver mutations were seen between $\mathrm{PB}$ and $\mathrm{BM}$ samples due to a shortage of leukemic blasts in the blood. Therefore, they recommended to use BM samples to monitor MRD in AML [87]. As described before, a study by Hourigan et al. used ultra-deep UMI-guided ECS to determine MRD status in frozen blood samples of AML patients in CR. The results indicated that $\mathrm{PB}$ can also be used to predict patient outcome by an NGS-based MRD assessment with a more sensitive NGS assay [58]. In addition, a targeted NGS-based study using circulating cell-free DNA (ccfDNA) derived from PB and BM samples was tested for the existence of somatic mutations at diagnosis and in CR of 22 AML patients. Interestingly, 
some persistent mutations were only detected in ccfDNA, indicating that ccfDNA from PB can give complementary information to BM [88].

Overall, although the use of $\mathrm{PB}$ as source for MRD testing seems promising in several studies, its utility remains to be validated within a larger cohort of AML patients, possibly with different MRD thresholds, before it can be considered for routine clinical MRD testing.

\subsection{Single Cell Approaches}

Another challenge in molecular MRD testing is to deconstruct the complex genetic heterogeneity that accompanies AML in the MRD setting. During tumor evolution cells may acquire additional genetic abnormalities, resulting in sub-clonal tumor populations. NGS on the bulk of the tumor cells does not take this clonal architecture into consideration and may miss rare variants occurring in small subsets of cells. Moreover, bulk sequencing is incapable of characterizing changes in clonal diversity over time, making it difficult to interpret information about tumor evolution and its correlation with relapse. As AML may evolve linear or in a complex branched clonal architecture, the application of single-cell sequencing (SCS) can provide a better understanding of the molecular landscape of AML at diagnosis as well as during treatment.

Single-cell analyses can be performed by a commercially available technique, such as the MissionBio Tapestry, $10 \times$ Genomics, and Fluidigm among others. However, these techniques are currently met with several limitations, including high allelic dropout rates, small gene panels, a limited single-cell throughput [89], and as SCS is a relatively new approach in AML MRD detection, not many studies have been performed yet.

Recently, some studies have explored the efficiency of using single-cell genotyping to investigate clonal evolution and detect MRD in AML using the MissionBio Tapestry. An increased sensitivity of SCS compared to bulk sequencing with the detection of MRD at $0.12 \%$ was shown [90]. In addition, SCS revealed information about the clonal evolution in 14 AML patients, making it easier to distinguish mutations associated with $\mathrm{CH}$ [90]. In a larger exploratory study using SCS into clonal evolution of AML, 123 AML patients were sequenced at different time points. It was shown that by using this technique, differences can be observed in combinations of mutations that lead to clonal dominance, and that expansion of minor clones could lead to a change in the clonal architecture [91]. A recent addition to SCS is the incorporation of immunophenotypes, by simultaneously sequencing mutations and identifying cell-surface protein markers of AML clones. Only a few studies have put this technique into practice yet. Miles et al. observed that $C D 11 b$ expression co-occurred with sub-clones harboring a RAS mutation [91]. Another recent study explored the utility of proteogenomics in three AML patients, and concluded that it can potentially improve precision medicine in AML [92].

Altogether, SCS is a promising method for the detection of MRD in AML, with the potential to detect MRD cells, deconstruct the clonal architecture, and study the clonal evolution over time.

\section{Future Perspective of Molecular MRD Detection in AML}

Molecular monitoring of MRD in AML patients has recently become more prominent. Since the most widely used molecular technique (i.e., RQ-PCR) has limited applicability for only subsets of AML patients, there is an urgent need to utilize NGS for MRD monitoring. Although still in development, NGS MRD seems to have clear additive values for molecular MRD monitoring. Studies have shown that it can be applied to virtually all AML patients, predict the risk of relapse after therapy, determine patient-specific prognosis, aid in assigning consolidation treatment strategies following completion of standard therapy, and monitor the efficacy of treatment.

In the last decade multiple studies have emerged that explored the use of NGS-based methods to detect MRD in AML. Although all studies underlie the potential clinical utility of NGS-MRD detection, most studies were performed in relatively small cohorts, making it difficult to determine the value of the rare variants as targets for MRD analyses. Prior 
to being able to fully implement MRD assessment by NGS in routine clinical practice, several additional issues need to be addressed: most importantly improvement of the sensitivity and specificity of molecular assays, and a better distinction between $\mathrm{CH}$ and leukemic transforming mutations. Finally, harmonization will be essential to allow accurate comparison of NGS-based MRD results among centers and trials [9]. Consensus should be accomplished in various aspects such as selection of the most relevant molecular markers, sequencing approaches, sampling tissue (BM or $\mathrm{PB}$ ), and timing of sampling.

Author Contributions: Conceptualization, C.M.V. and A.S.A.A.H.; writing-original draft preparation, C.M.V., A.S.A.A.H. and D.H.; writing-review and editing, C.M.V., A.S.A.A.H., D.H. and P.J.M.V. All authors have read and agreed to the published version of the manuscript.

Funding: This research was funded by the Queen Wilhelmina Fund Foundation of the Dutch Cancer Society, grant number 12507.

Conflicts of Interest: The authors declare no conflict of interest.

\section{References}

1. Döhner, H.; Weisdorf, D.J.; Bloomfield, C.D. Acute Myeloid Leukemia. N. Engl. J. Med. 2015, 373, 1136-1152. [CrossRef] [PubMed]

2. Papaemmanuil, E.; Gerstung, M.; Bullinger, L.; Gaidzik, V.I.; Paschka, P.; Roberts, N.D.; Potter, N.E.; Heuser, M.; Thol, F.; Bolli, N.; et al. Genomic Classification and Prognosis in Acute Myeloid Leukemia. N. Engl. J. Med. 2016, 374, 2209-2221. [CrossRef]

3. Döhner, H.; Estey, E.; Grimwade, D.; Amadori, S.; Appelbaum, F.R.; Büchner, T.; Dombret, H.; Ebert, B.L.; Fenaux, P.; Larson, R.A.; et al. Diagnosis and management of AML in adults: 2017 ELN recommendations from an international expert panel. Blood 2017, 129, 424-447. [CrossRef] [PubMed]

4. Burnett, A.; Wetzler, M.; Löwenberg, B. Therapeutic advances in acute myeloid leukemia. J. Clin. Oncol. 2011, 29, 487-494. [CrossRef]

5. Ravandi, F.; Walter, R.B.; Freeman, S.D. Evaluating measurable residual disease in acute myeloid leukemia. Blood Adv. 2018, 2, 1356-1366. [CrossRef] [PubMed]

6. Hourigan, C.S.; Karp, J.E. Minimal residual disease in acute myeloid leukaemia. Nat. Rev. Clin. Oncol. 2013, 10, 460-471. [CrossRef]

7. Ossenkoppele, G.; Schuurhuis, G.J. MRD in AML: Does it already guide therapy decision-making? Hematology 2016, 2016 , 356-365. [CrossRef]

8. Ossenkoppele, G.J.; van de Loosdrecht, A.A.; Schuurhuis, G.J. Review of the relevance of aberrant antigen expression by flow cytometry in myeloid neoplasms. Br. J. Haematol. 2011, 153, 421-436. [CrossRef] [PubMed]

9. Schuurhuis, G.J.; Heuser, M.; Freeman, S.; Béne, M.C.; Buccisano, F.; Cloos, J.; Grimwade, D.; Haferlach, T.; Hills, R.K.; Hourigan, C.S.; et al. Minimal/measurable residual disease in AML: A consensus document from the European LeukemiaNet MRD Working Party. Blood 2018, 131, 1275-1291. [CrossRef]

10. Terwijn, M.; van Putten, W.L.J.; Kelder, A.; van der Velden, V.H.J.; Brooimans, R.A.; Pabst, T.; Maertens, J.; Boeckx, N.; de Greef, G.E.; Valk, P.J.M.; et al. High prognostic impact of flow cytometric minimal residual disease detection in acute myeloid leukemia: Data from the HOVON/SAKK AML 42A study. J. Clin. Oncol. 2013, 31, 3889-3897. [CrossRef] [PubMed]

11. Zeijlemaker, W.; Kelder, A.; Cloos, J.; Schuurhuis, G.J. Immunophenotypic Detection of Measurable Residual (Stem Cell) Disease Using LAIP Approach in Acute Myeloid Leukemia. Curr. Protoc. Cytom. 2019, 91, e66. [CrossRef]

12. Wood, B.L. Acute Myeloid Leukemia Minimal Residual Disease Detection: The Difference from Normal Approach. Curr. Protoc. Cytom. 2020, 93, e73. [CrossRef]

13. Feller, N.; van der Pol, M.A.; van Stijn, A.; Weijers, G.W.D.; Westra, A.H.; Evertse, B.W.; Ossenkoppele, G.J.; Schuurhuis, G.J. MRD parameters using immunophenotypic detection methods are highly reliable in predicting survival in acute myeloid leukaemia. Leukemia 2004, 18, 1380-1390. [CrossRef] [PubMed]

14. Vedula, R.S.; Lindsley, R.C. Measurement of Residual Disease in Acute Myeloid Leukemia. Curr. Hematol. Malig. Rep. 2017, 12, 574-581. [CrossRef] [PubMed]

15. Hokland, P.; Ommen, H.B. Towards individualized follow-up in adult acute myeloid leukemia in remission. Blood 2011, 117, 2577-2584. [CrossRef]

16. Sangle, N.A.; Perkins, S.L. Core-binding factor acute myeloid leukemia. Arch. Pathol. Lab. Med. 2011, 135, 1504-1509. [CrossRef] [PubMed]

17. Yin, J.A.L.; O’Brien, M.A.; Hills, R.K.; Daly, S.B.; Wheatley, K.; Burnett, A.K. Minimal residual disease monitoring by quantitative RT-PCR in core binding factor AML allows risk stratification and predicts relapse: Results of the United Kingdom MRC AML-15 trial. Blood 2012, 120, 2826-2835. [CrossRef]

18. Jourdan, E.; Boissel, N.; Chevret, S.; Delabesse, E.; Renneville, A.; Cornillet, P.; Blanchet, O.; Cayuela, J.M.; Recher, C.; Raffoux, E.; et al. Prospective evaluation of gene mutations and minimal residual disease in patients with core binding factor acute myeloid leukemia. Blood 2013, 121, 2213-2223. [CrossRef] [PubMed] 
19. Corbacioglu, A.; Scholl, C.; Schlenk, R.F.; Eiwen, K.; Du, J.; Bullinger, L.; Fröhling, S.; Reimer, P.; Rummel, M.; Derigs, H.G.; et al. Prognostic impact of minimal residual disease in CBFB-MYH11-positive acute myeloid leukemia. J. Clin. Oncol. 2010, 28, 3724-3729. [CrossRef] [PubMed]

20. Krauter, J.; Görlich, K.; Ottmann, O.; Lübbert, M.; Döhner, H.; Heit, W.; Kanz, L.; Ganser, A.; Heil, G. Prognostic value of minimal residual disease quantification by real-time reverse transcriptase polymerase chain reaction in patients with core binding factor leukemias. J. Clin. Oncol. 2003, 21, 4413-4422. [CrossRef]

21. Grimwade, D.; Ivey, A.; Huntly, B.J.P. Molecular landscape of acute myeloid leukemia in younger adults and its clinical relevance. Blood 2016, 127, 29-41. [CrossRef]

22. Falini, B.; Brunetti, L.; Sportoletti, P.; Martelli, M.P. NPM1-mutated acute myeloid leukemia: From bench to bedside. Blood 2020, 136, 1707-1721. [CrossRef]

23. Krönke, J.; Bullinger, L.; Teleanu, V.; Tschürtz, F.; Gaidzik, V.I.; Kühn, M.W.M.; Rücker, F.G.; Holzmann, K.; Paschka, P.; KappSchwörer, S.; et al. Clonal evolution in relapsed NPM1-mutated acute myeloid leukemia. Blood 2013, 122, 100-108. [CrossRef]

24. Krönke, J.; Schlenk, R.F.; Jensen, K.O.; Tschürtz, F.; Corbacioglu, A.; Gaidzik, V.I.; Paschka, P.; Onken, S.; Eiwen, K.; Habdank, M.; et al. Monitoring of minimal residual disease in NPM1-mutated acute myeloid leukemia: A study from the German-Austrian acute myeloid leukemia study group. J. Clin. Oncol. 2011, 29, 2709-2716. [CrossRef] [PubMed]

25. Gorello, P.; Cazzaniga, G.; Alberti, F.; Dell’Oro, M.G.; Gottardi, E.; Specchia, G.; Roti, G.; Rosati, R.; Martelli, M.F.; Diverio, D.; et al. Quantitative assessment of minimal residual disease in acute myeloid leukemia carrying nucleophosmin (NPM1) gene mutations. Leukemia 2006, 20, 1103-1108. [CrossRef] [PubMed]

26. Ivey, A.; Hills, R.K.; Simpson, M.A.; Jovanovic, J.V.; Gilkes, A.; Grech, A.; Patel, Y.; Bhudia, N.; Farah, H.; Mason, J.; et al. Assessment of Minimal Residual Disease in Standard-Risk AML. N. Engl. J. Med. 2016, 374, 422-433. [CrossRef] [PubMed]

27. Shayegi, N.; Kramer, M.; Bornhäuser, M.; Schaich, M.; Schetelig, J.; Platzbecker, U.; Röllig, C.; Heiderich, C.; Landt, O.; Ehninger, G.; et al. The level of residual disease based on mutant NPM1 is an independent prognostic factor for relapse and survival in AML. Blood 2013, 122, 83-92. [CrossRef] [PubMed]

28. Schnittger, S.; Kern, W.; Tschulik, C.; Weiss, T.; Dicker, F.; Falini, B.; Haferlach, C.; Haferlach, T. Minimal residual disease levels assessed by NPM1 mutation-specific RQ-PCR provide important prognostic information in AML. Blood 2009, 114, $2220-2231$. [CrossRef] [PubMed]

29. Ivey, A.; Hills, R.K.; Simpson, M.A.; Jovanovic, J.V.; Gilkes, A.F.; Patel, Y.; Bhudia, N.; Farah, H.; Mason, J.; Wall, K.; et al. Molecular Detection of Minimal Residual Disease Provides the Most Powerful Independent Prognostic Factor Irrespective of Clonal Architecture in Nucleophosmin (NPM1) Mutant Acute Myeloid Leukemia. Blood 2014, 124, 70. [CrossRef]

30. Hubmann, M.; Köhnke, T.; Hoster, E.; Schneider, S.; Dufour, A.; Zellmeier, E.; Fiegl, M.; Braess, J.; Bohlander, S.K.; Subklewe, M.; et al. Molecular response assessment by quantitative real-time polymerase chain reaction after induction therapy in NPM1mutated patients identifies those at high risk of relapse. Haematologica 2014, 99, 1317. [CrossRef] [PubMed]

31. Jain, P.; Kantarjian, H.; Patel, K.; Faderl, S.; Garcia-Manero, G.; Benjamini, O.; Borthakur, G.; Pemmaraju, N.; Kadia, T.; Daver, N.; et al. Mutated NPM1 in patients with acute myeloid leukemia in remission and relapse. Leuk. Lymphoma 2013, 55, 1337-1344. [CrossRef] [PubMed]

32. Dillon, R.; Hills, R.; Freeman, S.; Potter, N.; Jovanovic, J.; Ivey, A.; Kanda, A.S.; Runglall, M.; Foot, N.; Valganon, M.; et al. Molecular MRD status and outcome after transplantation in NPM1-mutated AML. Blood 2020, 135, 680-688. [CrossRef] [PubMed]

33. Gaidzik, V.I.; Weber, D.; Paschka, P.; Kaumanns, A.; Krieger, S.; Corbacioglu, A.; Krönke, J.; Kapp-Schwoerer, S.; Krämer, D.; Horst, H.-A.; et al. DNMT3A mutant transcript levels persist in remission and do not predict outcome in patients with acute myeloid leukemia. Leukemia 2017, 32, 30-37. [CrossRef] [PubMed]

34. Rautenberg, C.; Pechtel, S.; Hildebrandt, B.; Betz, B.; Dienst, A.; Nachtkamp, K.; Kondakci, M.; Geyh, S.; Wieczorek, D.; Haas, R.; et al. Wilms' Tumor 1 Gene Expression Using a Standardized European LeukemiaNet-Certified Assay Compared to Other Methods for Detection of Minimal Residual Disease in Myelodysplastic Syndrome and Acute Myelogenous Leukemia after Allogeneic Blood Stem Cell Transp. Biol. Blood Marrow Transplant. 2018, 24, 2337-2343. [CrossRef] [PubMed]

35. Malagola, M.; Skert, C.; Borlenghi, E.; Chiarini, M.; Cattaneo, C.; Morello, E.; Cancelli, V.; Cattina, F.; Cerqui, E.; Pagani, C.; et al. Postremission sequential monitoring of minimal residual disease by WT1 Q-PCR and multiparametric flow cytometry assessment predicts relapse and may help to address risk-adapted therapy in acute myeloid leukemia patients. Cancer Med. 2016, 5, 265-274. [CrossRef]

36. Cilloni, D.; Renneville, A.; Hermitte, F.; Hills, R.K.; Daly, S.; Jovanovic, J.V.; Gottardi, E.; Fava, M.; Schnittger, S.; Weiss, T.; et al. Real-time quantitative polymerase chain reaction detection of minimal residual disease by standardized WT1 assay to enhance risk stratification in acute myeloid leukemia: A European LeukemiaNet Study. J. Clin. Oncol. 2009, 27, 5195-5201. [CrossRef] [PubMed]

37. Marani, C.; Clavio, M.; Grasso, R.; Colombo, N.; Guolo, F.; Kunkl, A.; Ballerini, F.; Giannoni, L.; Ghiggi, C.; Fugazza, G.; et al. Integrating post induction WT1 quantification and flow-cytometry results improves minimal residual disease stratification in acute myeloid leukemia. Leuk. Res. 2013, 37, 1606-1611. [CrossRef]

38. Bacher, U.; Dicker, F.; Haferlach, C.; Alpermann, T.; Rose, D.; Kern, W.; Haferlach, T.; Schnittger, S. Quantification of rare NPM1 mutation subtypes by digital PCR. Br. J. Haematol. 2014, 167, 710-714. [CrossRef] 
39. Bill, M.; Grimm, J.; Jentzsch, M.; Kloss, L.; Goldmann, K.; Schulz, J.; Beinicke, S.; Häntschel, J.; Cross, M.; Vucinic, V.; et al. Digital droplet PCR-based absolute quantification of pre-transplant NPM1 mutation burden predicts relapse in acute myeloid leukemia patients. Ann. Hematol. 2018, 97, 1757-1765. [CrossRef]

40. Pettersson, L.; Alm, S.J.; Almstedt, A.; Chen, Y.; Orrsjö, G.; Shah-Barkhordar, G.; Zhou, L.; Kotarsky, H.; Vidovic, K.; Asp, J.; et al. Comparison of RNA- and DNA-based methods for measurable residual disease analysis in NPM1-mutated acute myeloid leukemia. Int. J. Lab. Hematol. 2021, 43, 664-674. [CrossRef] [PubMed]

41. Mencia-Trinchant, N.; Hu, Y.; Alas, M.A.; Ali, F.; Wouters, B.J.; Lee, S.; Ritchie, E.K.; Desai, P.; Guzman, M.L.; Roboz, G.J.; et al. Minimal Residual Disease Monitoring of Acute Myeloid Leukemia by Massively Multiplex Digital PCR in Patients with NPM1 Mutations. J. Mol. Diagn. 2017, 19, 537-548. [CrossRef] [PubMed]

42. Ferret, Y.; Boissel, N.; Helevaut, N.; Madic, J.; Nibourel, O.; Marceau-Renaut, A.; Bucci, M.; Geffroy, S.; Celli-Lebras, K.; Castaigne, S.; et al. Clinical relevance of IDH1/2 mutant allele burden during follow-up in acute myeloid leukemia. A study by the French ALFA group. Haematologica 2018, 103, 822. [CrossRef] [PubMed]

43. Grassi, S.; Guerrini, F.; Ciabatti, E.; Puccetti, R.; Salehzadeh, S.; Metelli, M.R.; Di Vita, A.; Domenichini, C.; Caracciolo, F.; et al. Digital Droplet PCR is a Specific and Sensitive Tool for Detecting IDH2 Mutations in Acute Myeloid LeuKemia Patients. Cancers 2020, 12, 1738. [CrossRef] [PubMed]

44. Winters, A.; Goosman, M.; Stevens, B.M.; Purev, E.; Smith, C.; Pollyea, D.A.; Jordan, C.T.; Gutman, J.A. Tracking of AMLAssociated Mutations Via Droplet Digital PCR Is Predictive of Outcomes Post-Transplant. Blood 2018, 132, 2138. [CrossRef]

45. Nakamura, S.; Yokoyama, K.; Shimizu, E.; Yusa, N.; Kondoh, K.; Ogawa, M.; Takei, T.; Kobayashi, A.; Ito, M.; Isobe, M.; et al. Prognostic impact of circulating tumor DNA status post-allogeneic hematopoietic stem cell transplantation in AML and MDS. Blood 2019, 133, 2682-2695. [CrossRef] [PubMed]

46. Yoest, J.M.; Shirai, C.L.; Duncavage, E.J. Sequencing-Based Measurable Residual Disease Testing in Acute Myeloid Leukemia. Front. Cell Dev. Biol. 2020, 8, 249. [CrossRef]

47. Duncavage, E.J.; Schroeder, M.C.; O’Laughlin, M.; Wilson, R.; MacMillan, S.; Bohannon, A.; Kruchowski, S.; Garza, J.; Du, F.; Hughes, A.E.O.; et al. Genome Sequencing as an Alternative to Cytogenetic Analysis in Myeloid Cancers. N. Engl. J. Med. 2021, 384, 924-935. [CrossRef]

48. Thol, F.; Kölking, B.; Damm, F.; Reinhardt, K.; Klusmann, J.H.; Reinhardt, D.; von Neuhoff, N.; Brugman, M.H.; Schlegelberger, B.; Suerbaum, S.; et al. Next-generation sequencing for minimal residual disease monitoring in acute myeloid leukemia patients with FLT3-ITD or NPM1 mutations. Genes Chromosom. Cancer 2012, 51, 689-695. [CrossRef] [PubMed]

49. Kohlmann, A.; Nadarajah, N.; Alpermann, T.; Grossmann, V.; Schindela, S.; Dicker, F.; Roller, A.; Kern, W.; Haferlach, C.; Schnittger, S.; et al. Monitoring of residual disease by next-generation deep-sequencing of RUNX1 mutations can identify acute myeloid leukemia patients with resistant disease. Leukemia 2014, 28, 129-137. [CrossRef]

50. Klco, J.M.; Miller, C.A.; Griffith, M.; Petti, A.; Spencer, D.H.; Ketkar-Kulkarni, S.; Wartman, L.D.; Christopher, M.; Lamprecht, T.L.; Helton, N.M.; et al. Association between mutation clearance after induction therapy and outcomes in acute myeloid leukemia. JAMA 2015, 314, 811-822. [CrossRef]

51. Getta, B.M.; Devlin, S.M.; Levine, R.L.; Arcila, M.E.; Mohanty, A.S.; Zehir, A.; Tallman, M.S.; Giralt, S.A.; Roshal, M. Multicolor Flow Cytometry and Multigene Next-Generation Sequencing Are Complementary and Highly Predictive for Relapse in Acute Myeloid Leukemia after Allogeneic Transplantation. Biol. Blood Marrow Transplant. 2017, 23, 1064-1071. [CrossRef]

52. Jongen-Lavrencic, M.; Grob, T.; Hanekamp, D.; Kavelaars, F.G.; al Hinai, A.; Zeilemaker, A.; Erpelinck-Verschueren, C.A.J.; Gradowska, P.L.; Meijer, R.; Cloos, J.; et al. Molecular Minimal Residual Disease in Acute Myeloid Leukemia. N. Engl. J. Med. 2018, 378, 1189-1199. [CrossRef]

53. Morita, K.; Kantarjian, H.M.; Wang, F.; Yan, Y.; Bueso-Ramos, C.; Sasaki, K.; Issa, G.C.; Wang, S.; Jorgensen, J.; Song, X.; et al. Clearance of somatic mutations at remission and the risk of relapse in acute myeloid leukemia. J. Clin. Oncol. 2018, 36, 1788-1797. [CrossRef]

54. Kim, T.H.; Moon, J.H.; Ahn, J.S.; Kim, Y.K.; Lee, S.S.; Ahn, S.Y.; Jung, S.H.; Yang, D.H.; Lee, J.J.; Choi, S.H.; et al. Next-generation sequencing-based posttransplant monitoring of acute myeloid leukemia identifies patients at high risk of relapse. Blood 2018, 132, 1604-1613. [CrossRef]

55. Thol, F.; Gabdoulline, R.; Liebich, A.; Klement, P.; Schiller, J.; Kandziora, C.; Hambach, L.; Stadler, M.; Koenecke, C.; Flintrop, M.; et al. Measurable residual disease monitoring by ngs before allogeneic hematopoietic cell transplantation in AML. Blood 2018, 132, 1703-1713. [CrossRef]

56. Press, R.D.; Eickelberg, G.; Froman, A.; Yang, F.; Stentz, A.; Flatley, E.M.; Fan, G.; Lim, J.Y.; Meyers, G.; Maziarz, R.T.; et al. Next-generation sequencing-defined minimal residual disease before stem cell transplantation predicts acute myeloid leukemia relapse. Am. J. Hematol. 2019, 94, 902-912. [CrossRef] [PubMed]

57. Balagopal, V.; Hantel, A.; Kadri, S.; Steinhardt, G.; Zhen, C.J.; Kang, W.; Wanjari, P.; Ritterhouse, L.L.; Stock, W.; Segal, J.P. Measurable residual disease monitoring for patients with acute myeloid leukemia following hematopoietic cell transplantation using error corrected hybrid capture next generation sequencing. PLoS ONE 2019, 14, e0224097. [CrossRef] [PubMed]

58. Hourigan, C.S.; Dillon, L.W.; Gui, G.; Logan, B.R.; Fei, M.; Ghannam, J.; Li, Y.; Licon, A.; Alyea, E.P.; Bashey, A.; et al. Impact of conditioning intensity of allogeneic transplantation for acute myeloid leukemia with genomic evidence of residual disease. J. Clin. Oncol. 2020, 38, 1273-1283. [CrossRef] 
59. Heuser, M.; Heida, B.; Büttner, K.; Wienecke, C.P.; Teich, K.; Funke, C.; Brandes, M.; Klement, P.; Liebich, A.; Wichmann, M.; et al. Posttransplantation MRD monitoring in patients with AML by next-generation sequencing using DTA and non-DTA mutations. Blood Adv. 2021, 5, 2294-2304. [CrossRef]

60. Tsai, C.-H.; Tang, J.-L.; Tien, F.-M.; Kuo, Y.-Y.; Wu, D.-C.; Lin, C.-C.; Tseng, M.-H.; Peng, Y.-L.; Hou, M.-F.; Chuang, Y.-K.; et al. Clinical implications of sequential MRD monitoring by NGS at 2 time points after chemotherapy in patients with AML. Blood Adv. 2021, 5, 2456-2466. [CrossRef] [PubMed]

61. Kim, H.-J.; Kim, Y.; Kang, D.; Kim, H.S.; Lee, J.-M.; Kim, M.; Cho, B.-S. Prognostic value of measurable residual disease monitoring by next-generation sequencing before and after allogeneic hematopoietic cell transplantation in acute myeloid leukemia. Blood Cancer J. 2021, 11, 1-11. [CrossRef]

62. Jentzsch, M.; Grimm, J.; Bill, M.; Küpper, J.; Backhaus, D.; Brauer, D.; Schulz, J.; Franke, G.-N.; Vucinic, V.; Niederwieser, D.; et al. Measurable residual disease of canonical versus non-canonical DNMT3A, TET2, or ASXL1 mutations in AML at stem cell transplantation. Bone Marrow Transplant. 2021, 25, 2610-2612. [CrossRef]

63. Cappelli, L.V.; Meggendorfer, M.; Baer, C.; Nadarajah, N.; Hutter, S.; Jeromin, S.; Dicker, F.; Kern, W.; Haferlach, T.; Haferlach, C.; et al. Indeterminate and oncogenic potential: CHIP vs CHOP mutations in AML with NPM1 alteration. Leukemia 2021. [CrossRef] [PubMed]

64. Terwijn, M.; Zeijlemaker, W.; Kelder, A.; Rutten, A.P.; Snel, A.N.; Scholten, W.J.; Pabst, T.; Verhoef, G.; Löwenberg, B.; Zweegman, S.; et al. Leukemic Stem Cell Frequency: A Strong Biomarker for Clinical Outcome in Acute Myeloid Leukemia. PLoS ONE 2014, 9, e107587. [CrossRef] [PubMed]

65. Guolo, F.; Minetto, P.; Galaverna, F.; Guardo, D.; Colombo, N.; Kunkl, A.; Clavio, M.; Di Grazia, C.; Raiola, A.M.; Ballerini, F.; et al. Combining Flow Cytometry and Molecular Assessment Improves the Prognostic Value of Pre-Transplant Minimal Residual Disease in Acute Myeloid Leukemia. Blood 2016, 128, 521. [CrossRef]

66. Patkar, N.; Kakirde, C.; Shaikh, A.F.; Salve, R.; Bhanshe, P.; Chatterjee, G.; Rajpal, S.; Joshi, S.; Chaudhary, S.; Kodgule, R.; et al. Clinical impact of panel-based error-corrected next generation sequencing versus flow cytometry to detect measurable residual disease (MRD) in acute myeloid leukemia (AML). Leukemia 2021, 35, 1392-1404. [CrossRef]

67. Pfeiffer, F.; Gröber, C.; Blank, M.; Händler, K.; Beyer, M.; Schultze, J.L.; Mayer, G. Systematic evaluation of error rates and causes in short samples in next-generation sequencing. Sci. Rep. 2018, 8, 1-14. [CrossRef]

68. Salk, J.J.; Schmitt, M.W.; Loeb, L.A. Enhancing the accuracy of next-generation sequencing for detecting rare and subclonal mutations. Nat. Rev. Genet. 2018, 19, 269-285. [CrossRef]

69. Reha-Krantz, L.J. DNA polymerase proofreading: Multiple roles maintain genome stability. Biochim. Biophys. Acta-Proteins Proteom. 2010, 1804, 1049-1063. [CrossRef]

70. Spencer, D.H.; Tyagi, M.; Vallania, F.; Bredemeyer, A.J.; Pfeifer, J.D.; Mitra, R.D.; Duncavage, E.J. Performance of Common Analysis Methods for Detecting Low-Frequency Single Nucleotide Variants in Targeted Next-Generation Sequence Data. J. Mol. Diagn. 2014, 16, 75-88. [CrossRef]

71. Costello, M.; Fleharty, M.; Abreu, J.; Farjoun, Y.; Ferriera, S.; Holmes, L.; Granger, B.; Green, L.; Howd, T.; Mason, T.; et al. Characterization and remediation of sample index swaps by non-redundant dual indexing on massively parallel sequencing platforms. BMC Genom. 2018, 19. [CrossRef]

72. Ghannam, J.; Dillon, L.W.; Hourigan, C.S. Next-generation sequencing for measurable residual disease detection in acute myeloid leukaemia. Br. J. Haematol. 2020, 188, 77-85. [CrossRef]

73. Steensma, D.P. Clinical Implications of Clonal Hematopoiesis. Mayo Clin. Proc. 2018, 93, 1122-1130. [CrossRef] [PubMed]

74. Hasserjian, R.P.; Steensma, D.P.; Graubert, T.A.; Ebert, B.L. Clonal hematopoiesis and measurable residual disease assessment in acute myeloid leukemia. Blood 2020, 135, 1729-1738. [CrossRef]

75. Shlush, L.I.; Zandi, S.; Mitchell, A.; Chen, W.C.; Brandwein, J.M.; Gupta, V.; Kennedy, J.A.; Schimmer, A.D.; Schuh, A.C.; Yee, K.W.; et al. Identification of pre-leukaemic haematopoietic stem cells in acute leukaemia. Nature 2014, 506, 328-333. [CrossRef]

76. Zviran, A.; Schulman, R.C.; Shah, M.; Hill, S.T.K.; Deochand, S.; Khamnei, C.C.; Maloney, D.; Patel, K.; Liao, W.; Widman, A.J.; et al. Genome-wide cell-free DNA mutational integration enables ultra-sensitive cancer monitoring. Nat. Med. 2020, 26, 1114-1124. [CrossRef]

77. Blätte, T.J.; Schmalbrock, L.K.; Skambraks, S.; Lux, S.; Cocciardi, S.; Dolnik, A.; Döhner, H.; Döhner, K.; Bullinger, L. getITD for FLT3 -ITD-based MRD monitoring in AML. Leukemia 2019, 33, 2535-2539. [CrossRef]

78. Pickles, J.C.; Stone, T.J.; Jacques, T.S. Methylation-based algorithms for diagnosis: Experience from neuro-oncology. J. Pathol. 2020, 250, 510-517. [CrossRef] [PubMed]

79. Figueroa, M.E.; Abdel-Wahab, O.; Lu, C.; Ward, P.S.; Patel, J.; Shih, A.; Li, Y.; Bhagwat, N.; Vasanthakumar, A.; Fernandez, H.F.; et al. Leukemic IDH1 and IDH2 Mutations Result in a Hypermethylation Phenotype, Disrupt TET2 Function, and Impair Hematopoietic Differentiation. Cancer Cell 2010, 18, 553-567. [CrossRef] [PubMed]

80. Agrawal, S.; Unterberg, M.; Koschmieder, S.; zur Stadt, U.; Brunnberg, U.; Verbeek, W.; Büchner, T.; Berdel, W.E.; Serve, H.; Müller-Tidow, C. DNA Methylation of Tumor Suppressor Genes in Clinical Remission Predicts the Relapse Risk in Acute Myeloid Leukemia. Cancer Res. 2007, 67, 1370-1377. [CrossRef]

81. Božić, T.; Kuo, C.-C.; Hapala, J.; Franzen, J.; Eipel, M.; Platzbecker, U.; Kirschner, M.; Beier, F.; Jost, E.; Thiede, C.; et al. Investigation of measurable residual disease in acute myeloid leukemia by DNA methylation patterns. Leukemia 2021. [CrossRef] 
82. Leroy, H.; de Botton, S.; Gradel-Duflos, N.; Darre, S.; Leleu, X.; Roumier, C.; Morschhauser, F.; Lai, J.L.; Bauters, F.; Fenaux, P.; et al. Prognostic value of real-time quantitative PCR (RQ-PCR) in AML with $\mathrm{t}(8 ; 21)$. Leukemia 2005, 19, 367-372. [CrossRef] [PubMed]

83. Maurillo, L.; Buccisano, F.; Spagnoli, A.; Del Poeta, G.; Panetta, P.; Neri, B.; Del Principe, M.I.; Mazzone, C.; Consalvo, M.I.; Tamburini, A.; et al. Monitoring of minimal residual disease in adult acute myeloid leukemia using peripheral blood as an alternative source to bone marrow. Haematologica 2007, 92, 605-611. [CrossRef]

84. Zeijlemaker, W.; Kelder, A.; Oussoren-Brockhoff, Y.J.M.; Scholten, W.J.; Snel, A.N.; Veldhuizen, D.; Cloos, J.; Ossenkoppele, G.J.; Schuurhuis, G.J. Peripheral blood minimal residual disease may replace bone marrow minimal residual disease as an immunophenotypic biomarker for impending relapse in acute myeloid leukemia. Leukemia 2016, 30, 708-715. [CrossRef] [PubMed]

85. Godwin, C.D.; Zhou, Y.; Othus, M.; Asmuth, M.M.; Shaw, C.M.; Gardner, K.M.; Wood, B.L.; Walter, R.B.; Estey, E.H. Acute myeloid leukemia measurable residual disease detection by flow cytometry in peripheral blood vs bone marrow. Blood 2021, 137, 569-572. [CrossRef]

86. Aguirre-Ruiz, P.; Ariceta, B.; Viguria, M.C.; Zudaire, M.T.; Blasco-Iturri, Z.; Arnedo, P.; Aguilera-Diaz, A.; Jauregui, A.; Mañú, A.; Prosper, F.; et al. Assessment of Minimal Residual Disease by Next Generation Sequencing in Peripheral Blood as a Complementary Tool for Personalized Transplant Monitoring in Myeloid Neoplasms. J. Clin. Med. 2020, 9, 3818. [CrossRef]

87. Lucas, F.; Michaels, P.D.; Wang, D.; Kim, A.S. Mutational analysis of hematologic neoplasms in 164 paired peripheral blood and bone marrow samples by next-generation sequencing. Blood Adv. 2020, 4, 4362-4365. [CrossRef]

88. Short, N.J.; Patel, K.P.; Albitar, M.; Franquiz, M.; Luthra, R.; Kanagal-Shamanna, R.; Wang, F.; Assi, R.; Montalban-Bravo, G.; Matthews, J.; et al. Targeted next-generation sequencing of circulating cell-free DNA vs bone marrow in patients with acute myeloid leukemia. Blood Adv. 2020, 4, 1670-1677. [CrossRef]

89. Chen, A.; Hu, S.; Wang, Q.-F. Tumor heterogeneity of acute myeloid leukemia: Insights from single-cell sequencing. Blood Sci. 2019, 1, 73-76. [CrossRef]

90. Ediriwickrema, A.; Aleshin, A.; Reiter, J.G.; Corces, M.R.; Kohnke, T.; Stafford, M.; Liedtke, M.; Medeiros, B.C.; Majeti, R. Single-cell mutational profiling enhances the clinical evaluation of AML MRD. Blood Adv. 2020, 4, 943-952. [CrossRef] [PubMed]

91. Miles, L.A.; Bowman, R.L.; Merlinsky, T.R.; Csete, I.S.; Ooi, A.T.; Durruthy-Durruthy, R.; Bowman, M.; Famulare, C.; Patel, M.A.; Mendez, P.; et al. Single-cell mutation analysis of clonal evolution in myeloid malignancies. Nature 2020, 587, 477-482. [CrossRef] [PubMed]

92. Dillon, L.W.; Ghannam, J.; Nosiri, C.; Gui, G.; Goswami, M.; Calvo, K.R.; Lindblad, K.E.; Oetjen, K.A.; Wilkerson, M.; Soltis, A.R.; et al. Personalized Single-Cell Proteogenomics to Distinguish Acute Myeloid Leukemia from Non-Malignant Clonal Hematopoiesis. Blood Cancer Discov. 2021, 2, 319. [CrossRef] [PubMed] 